
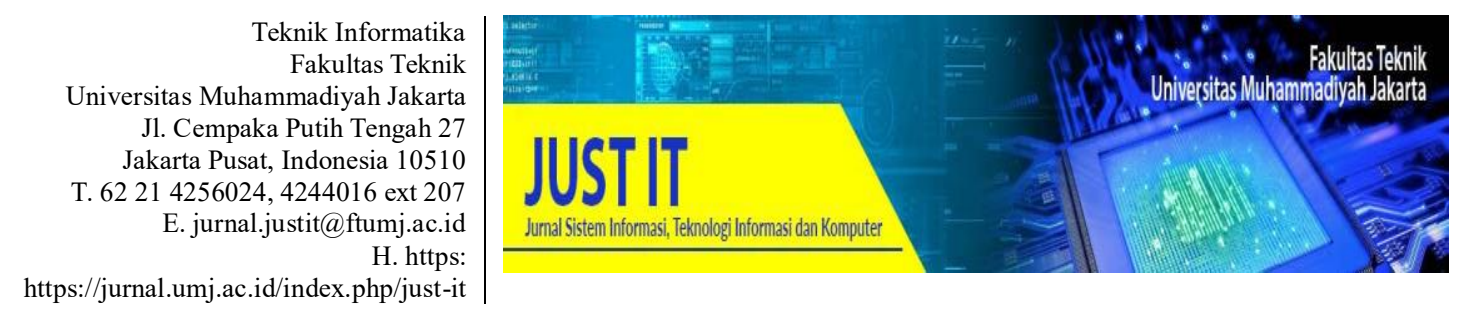

\title{
APLIKASI PEMILIHAN KARYAWAN TERBAIK DENGAN METODE SIMPLE ADDITIVE WEIGHTING (STUDI KASUS CITRA WIDYA TEKNIK)
}

\author{
Devi Witasari ${ }^{1}$, Yuwan Jumaryadi ${ }^{2}$ \\ Jurusan Sistem Informasi, Fakultas Ilmu Komputer, Universitas Mercu Buana \\ 41816010004@student.mercubuana.ac.id'1,yuwan.jumaryadi@mercubuana.ac.id²
}

\begin{abstract}
Abstrak
Aplikasi Pemilihan Karyawan Terbaik merupakan bagian dari Sistem Pendukung Keputusan. Citra Widya Teknik dijadikan tempat penelitian, dikarenakan dalam evaluasi kinerja dan pemilihan karyawan terbaik masih menggunakan sistem pengamatan, yang tentunya hal ini membutuhkan waktu lama serta penilaian menjadi kurang objektif. Penilaian ini memiliki 4 kriteria : Tanggung Jawab, Pengetahuan Pekerjaan, Kerjasama, Kualitas Pekerjaan dengan menggunakan metode Simple Additive Weighting (SAW). Metode penelitian yang digunakan dalam penelitian ini adalah wawancara, observasi dan studi literatur. Metode pengembangan sistem menggunakan metode Waterfall, dan aplikasi dirancang menggunakan bahasa pemrograman PHP dan database MySQL. Dari perhitungan pengujian didapatkan akurasi data sejumlah $100 \%$, yaitu perhitungan manual dan perhitungan aplikasi hasilnya sesuai yang diharapkan. Hasil penelitian ini menghasilkan sebuah aplikasi pemilihan karyawan terbaik yang digunakan untuk pemberian penghargaan/reward.
\end{abstract}

Kata Kunci: Karyawan Terbaik, Simple Additive Weighting, SPK, Perangkingan, Citra Widya Teknik

\begin{abstract}
The Best Employee Selection application is part of the decision support system. Citra Widya Teknik was used as a place of research, because in the evaluation of performance and selection of the best employees still use the observation system, which of course this requires a long time and the assessment becomes less objective. This assessment has 4 criteria: Responsibility, Job Knowledge, Cooperation, Quality of Work using the method Simple Additive Weighting (SAW). The research methods used in this study were interviews, observation and literature study. The system development method uses the Waterfall method, and the application is designed using the PHP programming languange and MySQL database. From the test calculation, the data accuracy is $100 \%$, namely manual calculation and application calculation results are as expected. The results of this study resulted in an application for selecting the best employees to use for awarding/rewards.
\end{abstract}

Keywords: Best Employees, Simple Additive Weighting, SPK, Ranking, Citra Widya Teknik

\section{Pendahuluan}

Semakin pesatnya perkembangan teknologi informasi pada era globalisasi, menjadi salah satu bukti nyata bahwa pemanfaatan teknologi informasi memberikan banyak kemudahan dalam aktivitas bisnis. Sumber daya manusia pun memegang 
kedudukan yang berpengaruh dalam aktivitas atau kegiatan untuk kemajuan perusahaan (Windarto, 2017).

Karyawan merupakan sumber daya manusia yang digunakan sebagai alat penggerak dalam roda bisnis suatu perusahaan. Perusahaan memiliki tantangan untuk menjaga eksistensial dalam bersaing yang tentunya memerlukan hasil data dari kinerja karyawan yang mempunyai kinerja baik. Kualitas kinerja karyawan diperlukan untuk meningkatkan produktivitas suatu perusahaan. Untuk memenuhi standar kualitas tersebut maka perusahaan perlu melakukan penilaian terhadap karyawannya agar mendapatkan standar kualitas karyawan terbaik yang sudah ditentukan berdasarkan kriteria oleh perusahaan.

Setiap harinya Citra Widya Teknik melayani sekitar 20-40 order serta memiliki 10 orang karyawan. Sistem yang digunakan CWT masih manual yaitu sistem pencatatan pada buku dalam pencarian data sehingga mengalami kesulitan. Begitu pun proses kegiatan penilaian kinerja karyawan masih menggunakan sistem pengamatan, yang tentunya hal ini membutuhkan waktu lama serta penilaian menjadi kurang objektif (Astuti \& Fu'ad, 2017), karena tidak berdasarkan perhitungan kriteria-kriteria yang sebagaimana mestinya.

Citra Widya Teknik telah berkomitmen untuk menjaga dan meningkatkan kualitas pelayanannya, yang dilakukan dengan cara mengevaluasi kinerja karyawannya dan memberikan reward berupa bonus ataupun kenaikan gaji kepada karyawan yang terbaik untuk memacu kinerja(Nashar et al., 2016).

Proses penilaian yang masih terbilang rumit, terkadang mengalami kesulitan dalam mengambil keputusan tersebut. Oleh karena itu, tujuan dan manfaat penelitian ini ialah untuk merancang dan membangun aplikasi pemilihan karyawan terbaik menggunakan metode Simple Additive Weighting (SAW), konsep metode ini menentukan nilai bobot untuk setiap atribut kemudian dilanjutkan dengan proses perangkingan yang akan menyeleksi alternatif terbaik, alternatif yaitu kriteria-kriteria yang ditentukan. Dengan metode perhitungan ini diharapkan perusahaan memperoleh hasil yang lebih cepat dan sesuai berdasarkan kebutuhan perusahaan.

\section{Tinjauan Pustaka}

\section{Sistem Pendukung Keputusan}

Sistem pendukung keputusan (SPK) sebagai sistem pendukung dalam mengambil keputusan yang memiliki kemampuan dalam memecahkan masalah untuk mencapai keinginan serta keuntungan bersama dan menghasilkan sebuah informasi yang akurat (Nashar et al., 2016). SPK di definisikan sebagai sistem untuk suatu pendekatan dalam pengambilan keputusan (Kurnianda, 2019).

\section{Karyawan}

Karyawan ialah pekerja yang yang memberikan sebuah jasa biasanya dalam bentuk tenaga ataupun pikiran dan mendapatkan upah berdasarkan perjanjian yang telah disepakati oleh bersama (Anto, Mustafidah, \& Suyadi, 2015). Definisi Karyawan menurut Undang-Undang Nomor 14 Tahun 1969 tentang ketentuan-ketentuan pokok mengenai ketenagakerjaan, karyawan didefinisikan sebagai orang yang mampu melakukan suatu pekerjaan/usaha, secara fisik ataupun pikiran untuk menghasilkan jasa ataupun barang guna memenuhi kebutuhan masyarakat

\section{Simple Additive Weighting (SAW)}

Simple Additive Weighting (SAW) adalah sebuah metode penjumlahan yang terpusat pada bobot. Yaitu dengan cara mencari nilai serta kinerja pada setiap alternatif di setiap kriteria yang telah ditentukan. Metode ini terdiri dari 2 atribut/kriteria yakni kriteria benefit (keuntungan) dan kriteria cost (biaya) (Wati \& Sadikin, 2019). Metode SAW harus dilakukan proses normalisasi matriks keputusan (x) ke suatu skala yang dapat diperbandingkan dengan semua alternatif yang ada (Triwahyuni, 2015).

Untuk merancang metode SAW ini, langkah- 
langkah yang dapat dilakukan antara lain :

1. Menentukan kriteria

2. Menetapkan bobot kriteria

3. Menentukan nilai alternatif dari kriteria

4. Melakukan proses hitung normalisasi

5. Melakukan proses hitung perangkingan.

6.Mengurutkan perangkingan dari nilai tertinggi sampai terendah.

7. Memperoleh hasil karyawan terbaik

Formula 1 untuk normalisasi ialah:

$$
\begin{gathered}
r_{i j}=\frac{X_{i j}}{\operatorname{Max}_{i} X_{i j}} \text { jika } j \text { adalah atribut keuntungan (biaya) } \\
r_{i j}=\frac{\operatorname{Min}_{i} X_{i j}}{X_{i j}} \text { jika } j \text { adalah atribut biaya (cost) }
\end{gathered}
$$

Keterangan:

$\mathrm{r}_{\mathrm{ij}} \quad=$ Rating kinerja ternormalisasi dari alternatif $\mathrm{Ai}$ pada atribut $\mathrm{Cj}$ $: i=1,2, \ldots, m$ dan $j=1,2, \ldots, n$

$\operatorname{Max}_{\mathrm{i}} \mathrm{X}_{\mathrm{ij}}=$ Nilai maksimum dari setiap kriteria i

$\operatorname{Min}_{\mathrm{i}} \mathrm{X}_{\mathrm{ij}}=$ Nilai minimum dari setiap kriteria $\mathrm{i}$

$\mathrm{X}_{\mathrm{ij}} \quad=$ Nilai atribut yang dimiliki dari setiap kriteria

Nilai preferensi Formula 2 untuk setiap alternatif (Vi) adalah:

$$
V_{i}=\sum_{j=1}^{n} W_{j} r_{i j}
$$

Keterangan:

$\mathrm{V}_{\mathrm{i}} \quad=$ Rangking untuk setiap alternatif

$\mathrm{W}_{\mathrm{j}} \quad=$ Nilai bobot rangking (dari setiap alternatif)

$\mathrm{r}_{\mathrm{ij}} \quad=$ Nilai rating kinerja ternormalisasi

Nilai $V_{i}$ yang lebih besar menyatakan bahwa alternatif $A_{i}$ lebih terpilih/terbaik.

\section{Metodologi Penelitian}

\section{Metode Pengumpulan Data}

1. Wawancara

Pada langkah ini dilakukan dengan melakukan wawancara kepada Owner Citra Widya Tehnik untuk memperoleh data yang diperlukan dan mengajukan beberapa pertanyaan yang terkait dengan penelitian.

2. Observasi

Observasi dilakukan dengan melihat secara langsung ke lokasi Citra Widya Tehnik guna mendapatkan informasi yang dibutuhkan.

3. Studi Literatur

Pada tahap ini dilakukan dengan mempelajari sumber-sumber atau buku-buku referensi yang terkait dengan metode SAW untuk bahan penelitian.

\section{Metode Pengembangan Sistem}

Metodologi pengembangan sistem yang digunakan adalah metode Waterfall. Metode ini bisa juga disebut (Classic Life Cycle), Metode ini lebih ke pendekatan yang berurutan dan sistematis dalam pengembangan sistem, metode ini di mulai dari spesifikasi kebutuhan pengguna kemudian berlanjut dengan tahapan komunikasi (communication), perencanaan (planning), pemodelan (modeling), konstruksi (construction), serta penyerahan sistem ke pengguna (deployment), dan diakhiri dengan (maintenance) pada sistem yang dihasilkan (Azza \& Dores, 2018).

\section{Hasil dan Pembahasan}

\section{Perencanaan Sistem}

Penentuan Pemilihan Karyawan Terbaik Di Citra Widya Teknik ada 4 kriteria yang digunakan untuk melakukan penilaian, yaitu:

TABEL 1

TABELKRITERIA

\begin{tabular}{|c|c|}
\hline Kriteria ( C ) & Keterangan \\
\hline $\mathrm{C} 1$ & Tanggung Jawab \\
\hline $\mathrm{C} 2$ & Pengetahuan Pekerjaan \\
\hline $\mathrm{C} 3$ & Kerjasama \\
\hline $\mathrm{C} 4$ & Kualitas Pekerjaan \\
\hline
\end{tabular}

$\mathrm{C} 1$ = Tanggung Jawab atas tugas yang dikerjakan

$\mathrm{C} 2=$ Pengetahuan Pekerjaan tentang AC 
C3 = Kerjasama tim

$\mathrm{C} 4=$ Kualitas pekerjaan/tugas yang dikerjakan berhasil atau komplain

TABEL 2

TABELNILAI PREFERENSI

\begin{tabular}{|c|c|}
\hline Keterangan Nilai & Nilai \\
\hline Sangat Baik & 4 \\
\hline Baik & 3 \\
\hline Cukup & 2 \\
\hline Buruk & 1 \\
\hline
\end{tabular}

Tabel 2. Menentukan nilai preferensi ini menggunakan bilangan fuzzy yang nantinya dapat di konversi ke dalam bilangan crips.

TABEL 3

TABEL BOBOT KRITERIA

\begin{tabular}{|c|c|c|}
\hline Kriteria (C) & Tipe Kriteria & Bobot Kriteria \\
\hline $\begin{array}{c}\text { Tanggung } \\
\text { Jawab }\end{array}$ & Benefit & 3 \\
\hline $\begin{array}{c}\text { Pengetahuan } \\
\text { Pekerjaan }\end{array}$ & Benefit & 2 \\
\hline Kerjasama & Benefit & 2 \\
\hline $\begin{array}{c}\text { Kualitas } \\
\text { Pekerjaan }\end{array}$ & Benefit & 3 \\
\hline
\end{tabular}

Pada Tabel diatas dijabarkan tipe masingmasing kriteria(benefit/cost) dan bobot kriteria

\section{Perancangan UML}

\section{Use Case Diagram}

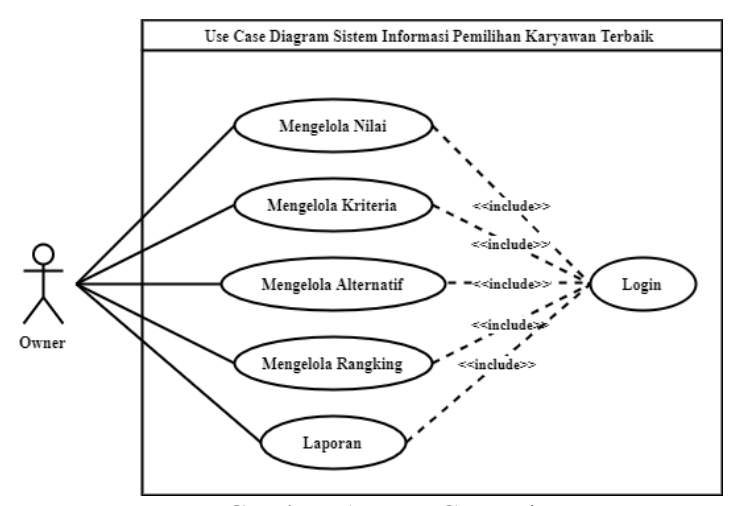

Gambar. 1. Use Case Diagram

Pada gambar 1 menjelaskan Use Case Diagram bahwa hanya ada 1 actor yaitu Owner, yang berperan dalam melakukan mengelola data karyawan, merubah data karyawan, dan menghapus data karyawan. Owner memiliki peran untuk melakukan perangkingan karyawan, dalam aksi ini owner juga berperan dalam hal ini, Owner juga berhak dalam memanajemen data serta kriteria seperti aksi ini yaitu dapat mengubah data kriteria, nilai, alternatif, dan rangking.

\section{Implementasi Sistem}

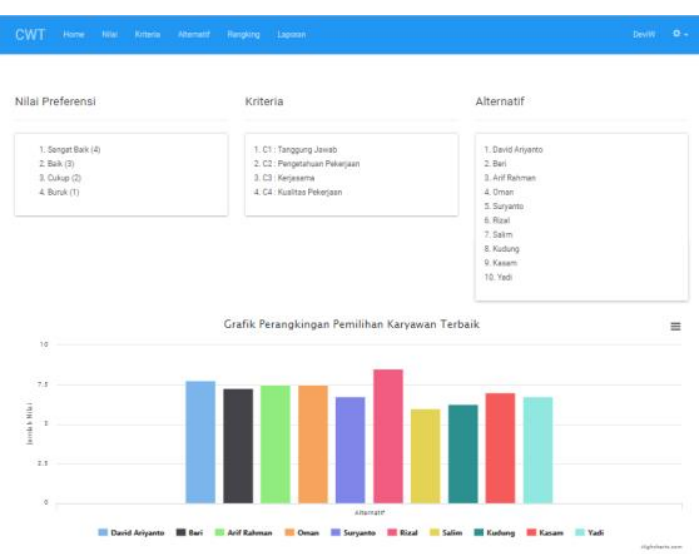

Gambar. 2. Halaman Menu Utama

Setelah proses login, akan masuk ke halaman menu utama, yang menampilkan nilai preferensi, kriteria, alternatif dan grafik hasil perangkingan karyawan terbaik.

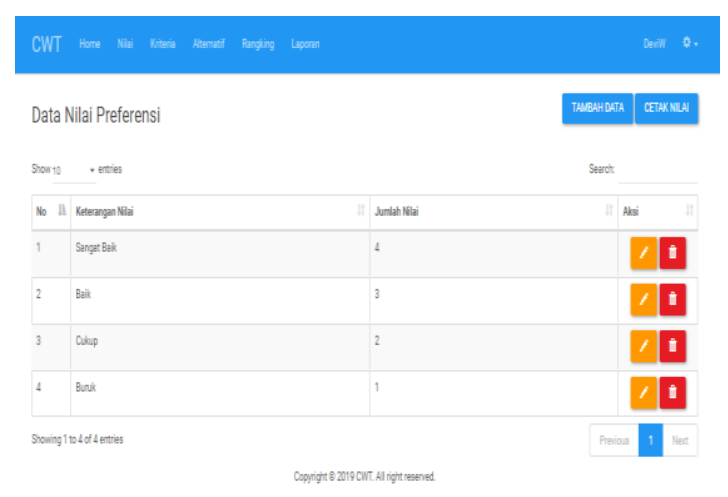

Gambar. 3. Halaman Nilai

Pada halaman nilai, dapat memasukkan nilai preferensi, mengedit dan menghapus. 


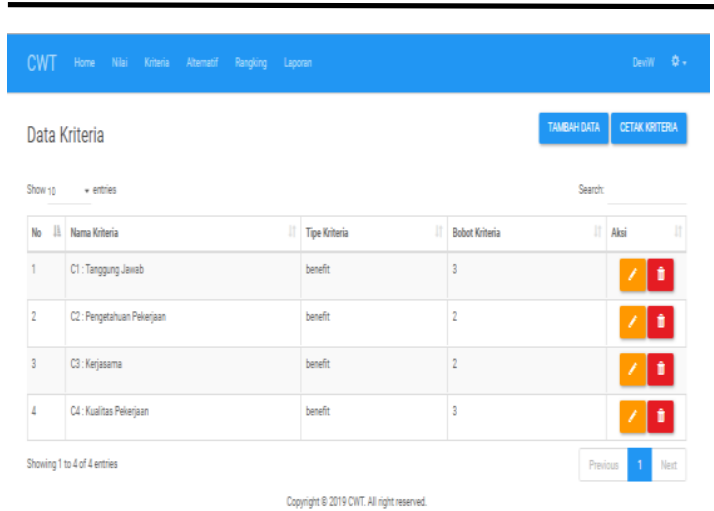

Gambar. 4. Halaman Kriteria

Pada halaman kriteria, dapat memasukkan, mengedit dan menghapus nama kriteria, tipe kriteria, dan bobot kriteria.

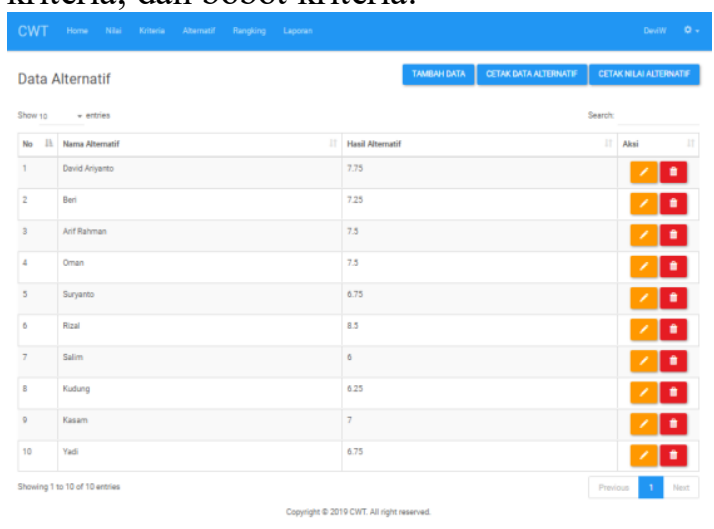

Gambar. 5. Halaman Alternatif

Pada halaman alternatif, dapat memasukkan, mengedit, dan menghapus nama alternatif.

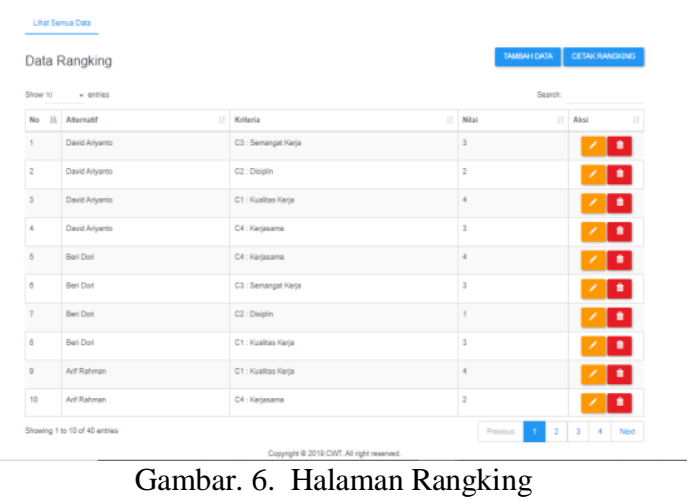

Pada halaman rangking, dapat memasukkan, mengedit, dan menghapus rangking.

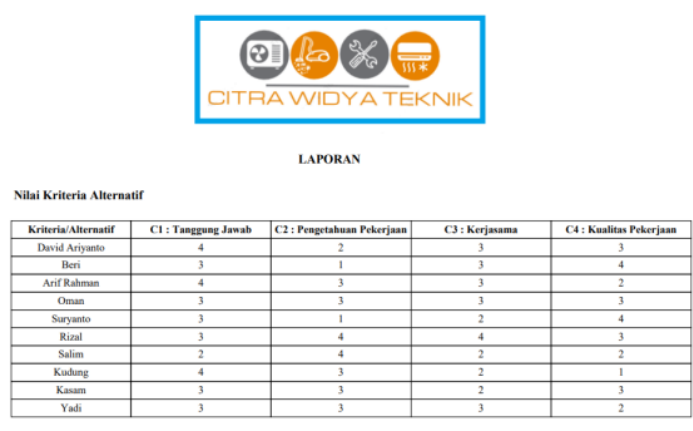

Gambar. 7. Cetak Kriteria Alternatif

Pada gambar 7, menampilkan hasil cetak Nilai Kriteria dari masing-masing Alternatif.

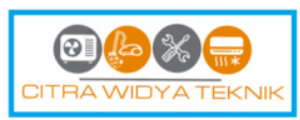

uporax

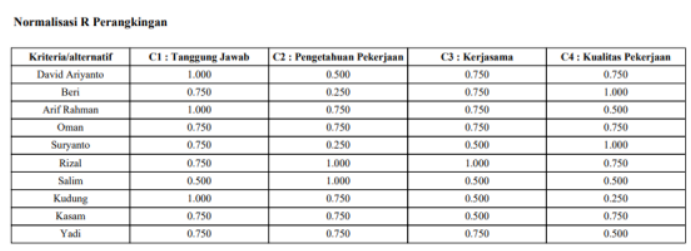

Gambar. 8. Cetak Normalisasi Rangking

Pada gambar 8, menampilkan hasil cetak Normalisasi Rangking yang diproses dengan rumus SAW.

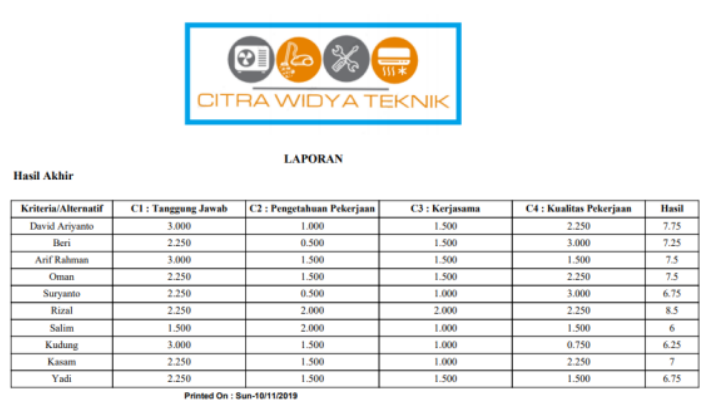

Gambar. 9. Cetak Hasil

Pada gambar 9, menampilkan hasil cetak perangkingan yang sudah diproses dengan rumus SAW. 


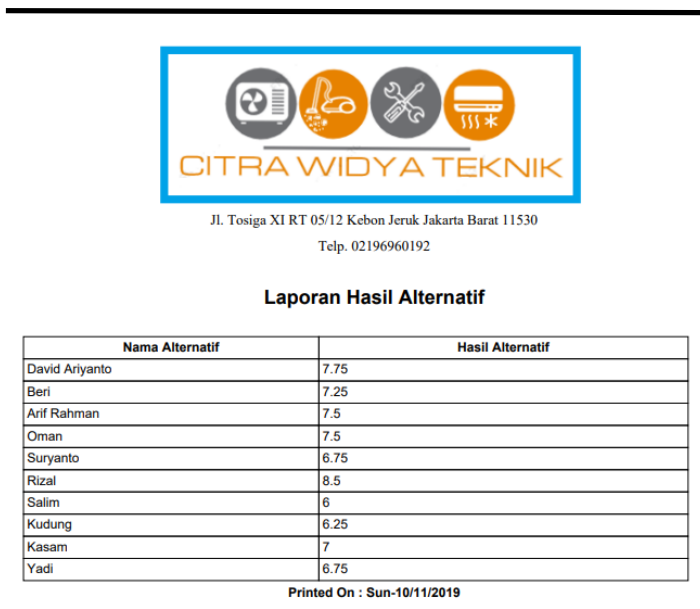

Gambar. 10. Halaman Cetak Laporan Hasil Akhir

Pada gambar 10, menampilkan cetak laporan hasil akhir. Yang memiliki hasil tertinggi adalah Rizal.

\section{Pengujian Metode SAW}

Pengujian dilakukan untuk mengetahui tingkat keakuratan dalam menentukan karyawan terbaik menggunakan Simple Additive Weighting(SAW).

TABEL 4

Data Pengujian

\begin{tabular}{|c|c|c|c|c|}
\hline Nama & C1 & C2 & C3 & C4 \\
\hline David A & $\begin{array}{c}\text { Sangat } \\
\text { baik }\end{array}$ & Cukup & Baik & Baik \\
\hline Beri & Baik & Buruk & Baik & $\begin{array}{c}\text { Sangat } \\
\text { baik }\end{array}$ \\
\hline Arif R & $\begin{array}{c}\text { Sangat } \\
\text { baik }\end{array}$ & Baik & Baik & Cukup \\
\hline Oman & Baik & Baik & Baik & Baik \\
\hline Suryanto & Baik & Buruk & Cukup & $\begin{array}{c}\text { Sangat } \\
\text { baik }\end{array}$ \\
\hline Rizal & Baik & $\begin{array}{c}\text { Sangat } \\
\text { baik }\end{array}$ & $\begin{array}{c}\text { Sangat } \\
\text { baik }\end{array}$ & Baik \\
\hline Salim & Cukup & $\begin{array}{c}\text { Sangat } \\
\text { baik }\end{array}$ & Cukup & Cukup \\
\hline Kudung & $\begin{array}{c}\text { Sangat } \\
\text { baik }\end{array}$ & Baik & Cukup & Buruk \\
\hline Kasam & Baik & Baik & Cukup & Baik \\
\hline Yadi & Baik & Baik & Baik & Cukup \\
\hline
\end{tabular}

TABEL 5

Validasi Nilai Alternatif

\begin{tabular}{|c|c|c|c|c|c|c|c|}
\hline \multirow[b]{2}{*}{$\begin{array}{l}\text { Karyaw } \\
\text { an/ } \\
\text { Alternat } \\
\text { if }\end{array}$} & \multicolumn{4}{|c|}{ Kriteria } & \multirow[b]{2}{*}{$\begin{array}{c}\text { Metode } \\
\text { Uji }\end{array}$} & \multicolumn{2}{|c|}{ Sesuai } \\
\hline & $\begin{array}{l}C \\
1\end{array}$ & $\begin{array}{l}\text { C } \\
2\end{array}$ & $\begin{array}{l}\text { C } \\
3\end{array}$ & $\begin{array}{l}C \\
4\end{array}$ & & $\begin{array}{l}\mathbf{Y} \\
\mathbf{a}\end{array}$ & $\begin{array}{l}\mathbf{T i} \\
\mathbf{d} \\
\mathbf{a} \\
\mathbf{k}\end{array}$ \\
\hline \multirow{2}{*}{ David A } & 4 & 2 & 3 & 3 & Aplikasi & $\checkmark$ & \\
\hline & 4 & 2 & 3 & 3 & Manual & $\checkmark$ & \\
\hline
\end{tabular}

\begin{tabular}{|c|c|c|c|c|c|c|}
\hline \multirow{2}{*}{ Beri } & 3 & 1 & 3 & 4 & Aplikasi & $\checkmark$ \\
\hline & 3 & 1 & 3 & 4 & Manual & $\checkmark$ \\
\hline \multirow{2}{*}{ Arif $\mathrm{R}$} & 4 & 3 & 3 & 2 & Aplikasi & $\checkmark$ \\
\hline & 4 & 3 & 3 & 2 & Manual & $\checkmark$ \\
\hline \multirow{2}{*}{ Oman } & 3 & 3 & 3 & 3 & Aplikasi & $\checkmark$ \\
\hline & 3 & 3 & 3 & 3 & Manual & $\checkmark$ \\
\hline \multirow{2}{*}{ Suryanto } & 3 & 1 & 2 & 4 & Aplikasi & $\checkmark$ \\
\hline & 3 & 1 & 2 & 4 & Manual & $\checkmark$ \\
\hline \multirow{2}{*}{ Rizal } & 3 & 4 & 4 & 3 & Aplikasi & $\checkmark$ \\
\hline & 3 & 4 & 4 & 3 & Manual & $\checkmark$ \\
\hline \multirow{2}{*}{ Salim } & 2 & 4 & 2 & 2 & Aplikasi & $\checkmark$ \\
\hline & 2 & 4 & 2 & 2 & Manual & $\checkmark$ \\
\hline \multirow{2}{*}{ Kudung } & 4 & 3 & 2 & 1 & Aplikasi & $\checkmark$ \\
\hline & 4 & 3 & 2 & 1 & Manual & $\checkmark$ \\
\hline \multirow[b]{2}{*}{ Kasam } & 3 & 3 & 2 & 3 & Aplikasi & $\checkmark$ \\
\hline & 3 & 3 & 2 & 3 & Manual & $\checkmark$ \\
\hline \multirow{2}{*}{ Yadi } & 3 & 3 & 3 & 2 & Aplikasi & $\checkmark$ \\
\hline & 3 & 3 & 3 & 2 & Manual & $\checkmark$ \\
\hline
\end{tabular}

Uji coba nilai alternatif pada aplikasi dan manual adalah sesuai.

TABEL 6

Validasi Matriks Normalisasi

\begin{tabular}{|c|c|c|c|c|c|c|c|}
\hline \multirow{2}{*}{$\begin{array}{c}\text { Kar } \\
\text { yaw } \\
\text { an/ } \\
\text { Alte } \\
\text { rnat } \\
\text { if }\end{array}$} & \multicolumn{4}{|c|}{ Kriteria } & \multirow[b]{2}{*}{$\begin{array}{c}\text { Metode } \\
\text { Uji }\end{array}$} & \multicolumn{2}{|c|}{$\begin{array}{l}\text { Sesua } \\
\text { i }\end{array}$} \\
\hline & C1 & $\mathrm{C} 2$ & C3 & $\mathrm{C} 4$ & & $\begin{array}{l}\mathbf{Y} \\
\mathbf{a}\end{array}$ & $\begin{array}{l}\text { T } \\
\text { i } \\
\text { d } \\
\text { a } \\
\text { k }\end{array}$ \\
\hline \multirow{2}{*}{$\begin{array}{l}\text { Dav } \\
\text { id A }\end{array}$} & 1 & 0.5 & 0.75 & 0.75 & Aplikas & $\checkmark$ & \\
\hline & 1 & 0.5 & 0.75 & 0.75 & Manual & $\checkmark$ & \\
\hline \multirow[t]{2}{*}{ Beri } & 0.75 & 0.25 & 0.75 & 1 & $\begin{array}{c}\text { Aplikas } \\
\mathrm{i}\end{array}$ & $\checkmark$ & \\
\hline & 0.75 & 0.25 & 0.75 & 1 & Manual & $\checkmark$ & \\
\hline \multirow{2}{*}{$\begin{array}{c}\text { Arif } \\
\mathrm{R}\end{array}$} & 1 & 0.75 & 0.75 & 0.5 & Aplikas & $\checkmark$ & \\
\hline & 1 & 0.75 & 0.75 & 0.5 & Manual & $\checkmark$ & \\
\hline \multirow{2}{*}{$\begin{array}{l}\text { Om } \\
\text { an }\end{array}$} & 0.75 & 0.75 & 0.75 & 0.75 & $\begin{array}{c}\text { Aplikas } \\
\text { i }\end{array}$ & $\checkmark$ & \\
\hline & 0.75 & 0.75 & 0.75 & 0.75 & Manual & $\checkmark$ & \\
\hline \multirow{2}{*}{$\begin{array}{c}\text { Sur } \\
\text { yant } \\
\text { o }\end{array}$} & 0.75 & 0.25 & 0.5 & 1 & $\begin{array}{c}\text { Aplikas } \\
\text { i }\end{array}$ & $\checkmark$ & \\
\hline & 0.75 & 0.25 & 0.5 & 1 & Manual & $\checkmark$ & \\
\hline \multirow{2}{*}{$\begin{array}{c}\text { Riza } \\
1\end{array}$} & 0.75 & 1 & 1 & 0.75 & Aplikas & $\checkmark$ & \\
\hline & 0.75 & 1 & 1 & 0.75 & Manual & $\checkmark$ & \\
\hline \multirow{2}{*}{$\begin{array}{l}\text { Sali } \\
\text { m }\end{array}$} & 0.5 & 1 & 0.5 & 0.5 & $\underset{\mathrm{i}}{\text { Aplikas }}$ & $\checkmark$ & \\
\hline & 0.5 & 1 & 0.5 & 0.5 & Manual & $\checkmark$ & \\
\hline \multirow{2}{*}{$\begin{array}{l}\text { Kud } \\
\text { ung }\end{array}$} & 1 & 0.75 & 0.5 & 0.25 & $\begin{array}{c}\text { Aplikas } \\
\text { i }\end{array}$ & $\checkmark$ & \\
\hline & 1 & 0.75 & 0.5 & 0.25 & Manual & $\checkmark$ & \\
\hline \multirow{2}{*}{$\begin{array}{c}\text { Kas } \\
\text { am }\end{array}$} & 0.75 & 0.75 & 0.5 & 0.75 & $\begin{array}{c}\text { Aplikas } \\
\mathrm{i}\end{array}$ & $\checkmark$ & \\
\hline & 0.75 & 0.75 & 0.5 & 0.75 & Manual & $\checkmark$ & \\
\hline \multirow[t]{2}{*}{ Yadi } & 0.75 & 0.75 & 0.75 & 0.5 & $\begin{array}{c}\text { Aplikas } \\
\mathrm{i}\end{array}$ & $\checkmark$ & \\
\hline & 0.75 & 0.75 & 0.75 & 0.5 & Manual & $\checkmark$ & \\
\hline
\end{tabular}


Uji coba matriks normalisasi pada aplikasi dan manual adalah sesuai.

TABEL 7

UJI COBA HASIL

\begin{tabular}{|c|c|c|c|c|c|c|c|}
\hline \multirow{2}{*}{$\begin{array}{c}\text { Kar } \\
\text { yaw } \\
\text { an/ } \\
\text { Alte } \\
\text { rnat } \\
\text { if }\end{array}$} & \multicolumn{4}{|c|}{ Kriteria } & \multirow[b]{2}{*}{$\begin{array}{c}\text { Metode } \\
\text { Uji }\end{array}$} & \multicolumn{2}{|c|}{$\begin{array}{l}\text { Sesua } \\
\text { i }\end{array}$} \\
\hline & $\mathrm{C} 1$ & $\mathrm{C2}$ & C3 & $\mathrm{C} 4$ & & $\begin{array}{l}\mathbf{Y} \\
\mathbf{a}\end{array}$ & $\begin{array}{l}\text { T } \\
\mathbf{i} \\
\mathbf{d} \\
\mathbf{a} \\
\mathrm{k}\end{array}$ \\
\hline \multirow{2}{*}{$\begin{array}{l}\text { Dav } \\
\text { id A }\end{array}$} & 3 & 1 & 1.5 & 2.25 & $\begin{array}{c}\text { Aplikas } \\
\text { i }\end{array}$ & $\checkmark$ & \\
\hline & 3 & 1 & 1.5 & 2.25 & Manual & $\checkmark$ & \\
\hline \multirow[t]{2}{*}{ Beri } & 2.25 & 0.5 & 1.5 & 3 & $\begin{array}{c}\text { Aplikas } \\
\text { i }\end{array}$ & $\checkmark$ & \\
\hline & 2.25 & 0.5 & 1.5 & 3 & Manual & $\checkmark$ & \\
\hline \multirow{2}{*}{$\begin{array}{c}\text { Arif } \\
\mathrm{R}\end{array}$} & 3 & 1.5 & 1.5 & 1.5 & $\underset{i}{\text { Aplikas }}$ & $\checkmark$ & \\
\hline & 3 & 1.5 & 1.5 & 1.5 & Manual & $\checkmark$ & \\
\hline \multirow{2}{*}{$\begin{array}{l}\text { Om } \\
\text { an }\end{array}$} & 2.25 & 1.5 & 1.5 & 2.25 & $\begin{array}{c}\text { Aplikas } \\
\text { i }\end{array}$ & $\checkmark$ & \\
\hline & 2.25 & 1.5 & 1.5 & 2.25 & Manual & $\checkmark$ & \\
\hline \multirow{2}{*}{$\begin{array}{c}\text { Sur } \\
\text { yant } \\
\text { o }\end{array}$} & 2.25 & 0.5 & 1 & 3 & $\begin{array}{c}\text { Aplikas } \\
\text { i }\end{array}$ & $\checkmark$ & \\
\hline & 2.25 & 0.5 & 1 & 3 & Manual & $\checkmark$ & \\
\hline \multirow{2}{*}{$\begin{array}{c}\text { Riza } \\
1\end{array}$} & 2.25 & 2 & 2 & 2.25 & $\underset{i}{\text { Aplikas }}$ & $\checkmark$ & \\
\hline & 2.25 & 2 & 2 & 2.25 & Manual & $\checkmark$ & \\
\hline \multirow{2}{*}{$\begin{array}{c}\text { Sali } \\
\text { m }\end{array}$} & 1.5 & 2 & 1 & 1.5 & $\begin{array}{c}\text { Aplikas } \\
\text { i }\end{array}$ & $\checkmark$ & \\
\hline & 1.5 & 2 & 1 & 1.5 & Manual & $\checkmark$ & \\
\hline \multirow{2}{*}{$\begin{array}{l}\text { Kud } \\
\text { ung }\end{array}$} & 3 & 1.5 & 1 & 0.75 & $\begin{array}{c}\text { Aplikas } \\
\text { i }\end{array}$ & $\checkmark$ & \\
\hline & 3 & 1.5 & 1 & 0.75 & Manual & $\checkmark$ & \\
\hline \multirow{2}{*}{$\begin{array}{l}\text { Kas } \\
\text { am }\end{array}$} & 2.25 & 1.5 & 1 & 2.25 & $\begin{array}{c}\text { Aplikas } \\
\text { i }\end{array}$ & $\checkmark$ & \\
\hline & 2.25 & 1.5 & 1 & 2.25 & Manual & $\checkmark$ & \\
\hline \multirow{2}{*}{ Yadi } & 2.25 & 1.5 & 1.5 & 1.5 & $\underset{\mathrm{i}}{\text { Aplikas }}$ & $\checkmark$ & \\
\hline & 2.25 & 1.5 & 1.5 & 1.5 & Manual & $\checkmark$ & \\
\hline
\end{tabular}

Tabel 7, uji coba hasil perhitungan akhir dari nilai preferensi pada aplikasi dan manual adalah sesuai.

Berikut adalah hasil dari hasil perangkingan seperti yang terlihat pada tabel 8 .

TABEL 8

HASIL PERANGKINGAN

\begin{tabular}{|c|c|c|c|c|c|}
\hline $\begin{array}{c}\text { Karya } \\
\text { wan/ } \\
\begin{array}{c}\text { Alterna } \\
\text { tif }\end{array}\end{array}$ & Total & $\begin{array}{c}\text { Rangki } \\
\text { ng }\end{array}$ & $\begin{array}{c}\text { Metode } \\
\text { Uji }\end{array}$ & $\begin{array}{c}\mathbf{Y} \\
\mathbf{a}\end{array}$ & $\begin{array}{c}\text { Ti } \\
\mathbf{d} \\
\mathbf{a} \\
\mathbf{k}\end{array}$ \\
\hline \multirow{2}{*}{ David A } & 7.75 & 2 & Aplikasi & $\checkmark$ & \\
\hline & 7.75 & 2 & Manual & $\checkmark$ & \\
\hline \multirow{2}{*}{ Beri } & 7.25 & 5 & Aplikasi & $\checkmark$ & \\
\hline & 7.25 & 5 & Manual & $\checkmark$ & \\
\hline
\end{tabular}

\begin{tabular}{|c|c|c|c|c|c|}
\hline \multirow{2}{*}{ Arif R } & 7.5 & 3 & Aplikasi & $\checkmark$ & \\
\cline { 2 - 7 } & 7.5 & 3 & Manual & $\checkmark$ & \\
\hline \multirow{2}{*}{ Oman } & 7.5 & 4 & Aplikasi & $\checkmark$ & \\
\cline { 2 - 7 } & 7.5 & 4 & Manual & $\checkmark$ & \\
\hline $\begin{array}{c}\text { Suryant } \\
\text { o }\end{array}$ & 6.75 & 7 & Aplikasi & $\checkmark$ & \\
\cline { 2 - 7 } Rizal & 6.75 & 7 & Manual & $\checkmark$ & \\
\cline { 2 - 7 } & 8.5 & 1 & Aplikasi & $\checkmark$ & \\
\hline \multirow{2}{*}{ Salim } & 8.5 & 1 & Manual & $\checkmark$ & \\
\cline { 2 - 7 } & 6 & 10 & Aplikasi & $\checkmark$ & \\
\hline \multirow{2}{*}{ Kudung } & 6.25 & 9 & Manual & $\checkmark$ & \\
\cline { 2 - 7 } & 6.25 & 9 & Manual & $\checkmark$ & \\
\hline \multirow{2}{*}{ Kasam } & 7 & 6 & Aplikasi & $\checkmark$ & \\
\cline { 2 - 7 } & 7 & 6 & Manual & $\checkmark$ & \\
\hline \multirow{2}{*}{ Yadi } & 6.75 & 8 & Aplikasi & $\checkmark$ & \\
\cline { 2 - 7 } & 6.75 & 8 & Manual & $\checkmark$ & \\
\hline
\end{tabular}

Pada hasil akhir, dapat dilihat bahwa pada perangkingan manual dan aplikasi hasilnya sesuai.

\section{Kesimpulan}

Dengan adanya Aplikasi Pemilihan Karyawan Terbaik membantu pengambilan keputusan dalam masalah pemilihan karyawan terbaik secara cepat berdasarkan kriteria yang ditetapkan. Metode Simple Additive Weighting sangat cocok digunakan untuk menentukan nilai tertinggi dari hasil penilaian karyawan. Penentuan nilai bobot kriteria sangat mempengaruhi nilai hasil perhitungan Simple Additive Weighting. Membantu seorang Owner CWT untuk menentukan penilaian karyawan dalam pemberian penghargaan/reward.

\section{Daftar Pustaka}

Anto, A. G., Mustafidah, H., \& Suyadi, A. (2015). Sistem Pendukung Keputusan Penilaian Kinerja Karyawan Menggunakan Metode SAW ( Simple Additive Weighting ). Juita, III(November), 193-200.

Astuti, Y., \& Isna Zahrotul Fu'ad. (2017). Penentuan Karyawan Terbaik Menggunakan Metode Simple Additive Weighting Pada PT. Patra Nur Alaska. Seminar Nasional Tekhnologi Informasi Dan Multimedia, 37-42. Retrieved from http://ojs.amikom.ac.id/index.php/semn a steknomedia/article/view/1699/1576

Azza, G. M., \& Dores, A. (2018). Sistem 
Informasi Manajemen Marketing Tools Serta Penerapan Metode Ahp (Analytical Hierarchy Process) Pada Proses Uji Kualitas Barang (Studi Kasus: PT Edi Indonesia). Jurnal Cendikia, XVI, 107114.

Kurnianda, N. R. (2019). Multi-Attribute Decision Making Model for Acceptance of Prospective Corporate Employees with Interpolation Method. Journal of Physics: Conference Series, 1179, 012006. https://doi.org/10.1088/17426596/1179/1/012006

Nashar, M., Sukamto, A., \& Parashakti, R. D. (2016). Sistem Penunjang Keputusan (Decision Support System DSS) untuk Pemilihan Karyawan Berprestasi dengan Metode Simple Additive Weighting (Studi Kasus di Akademi Telekomunikasi Bogor). Jurnal Ilmiah Manajemen Dan Bisnis, 2(3), 882-891.

Triwahyuni, A. (2015). TERBAIK CARREFOUR MENGGUNAKAN METODE SIMPLE ADDITIVE WEIGHTING ( SAW ). 15(1), 66-80.

Wati, Y. A., \& Sadikin, M. (2019). Sistem Pendukung Pengambilan Keputusan Prioritas Perbaikan Mold PT. Biggy Cemerlang dengan Menggunakan Metode SAW (Simple Additive Weighting). Jurnal Ilmu Teknik Dan Komputer, 3(1), 1-10.

Windarto, A. P. (2017). Penilaian Prestasi Kerja Karyawan PTPN III Pematangsiantar Dengan Metode Simple Additive Weighting (SAW). Jurasik (Jurnal Riset Sistem Informasi Dan Teknik Informatika), 2(1), 84. https://doi.org/10.30645/jurasik.v2i1.22 